\title{
Maimonides on Divine Religion
}

et us posit the following hypothetical situation: a Jew approaches Maimonides toward the end of the latter's life and addresses him as follows:

Teach us our master. In your conclusion to the Mishneh Torah (Laws of Kings and their Wars 12.1) you write that in the days of the messiah all humanity will return to the true religion (yabzeru qulam la-dat ba-emet), and in your treatise the term "true religion" refers specifically to Judaism. ${ }^{1}$ Does this mean that the entire world will eventually convert to Judaism?

In this situation as I imagine it, Maimonides hesitates for a brief of moment before answering affirmatively. In the messianic age, he proclaims, the entire world will convert to the one true divine religion, Judaism. In this chapter I will show why I am convinced that this is what Maimonides would answer, and why in the situation I envision he hesitates before responding. In this hesitation, he considers the issue

1 See, for example, Mishneb Torah, Laws of Leavened and Unleavened Bread 7.4; Laws of Gifts for the Poor 10.1; Laws of Hagigah 3.1; Laws of Kings 4.10. See also Book of Commandments, positive commandment no. 9 (in Arabic: al-din al-baquīa $\vec{\imath}$. 
from a number of perspectives that are discernible in his various writings. What these perspectives are will be the main subject of this chapter.

The issue that I raise is not a new one but has already been debated by scholars. The evidence for and against the conclusion that the whole world will convert to Judaism in the messianic times according to Maimonides is presented by Gerald Blidstein, who interprets Maimonides as avoiding the conclusion to which many of his express statements on the subject appear to lead. He feels that Maimonides views the gentiles in the messianic age as fellow travelers of the Jewish people, voluntarily engaging in many Jewish practices, without, however, becoming formal converts who observe the entire Torah. ${ }^{2}$ Menachem Kellner, on the other hand, sees Maimonides as positing a world in which all gentiles formally embrace Judaism. ${ }^{3}$ Other scholars have examined issues that have an important bearing on this problem. Joel Kraemer, for example, has studied Maimonides' use of the Arabic terms for law-namely, sharí'a, which generally denotes religious or divine law, and namus, which generally denotes civil or human law. Kraemer shows that this distinction does not characterize all of Maimonides' usages of these terms. ${ }^{4}$ Avraham Nuriel's subsequent study of the term shari' $a$ in Maimonides' writings adds some important points to Kraemer's analysis. Nuriel concludes that Maimonides may have regarded the seven Noahite laws as a divine law, though an

2 See Gerald Blidstein, Political Concepts in Maimonidean Halakha (Ramat-Gan: Bar-Ilan University Press, 2001), 245-248 (Heb.).

3 See Menachem Kellner, Maimonides on Judaism and the Jewish People (Albany: SUNY Press, 1991), 39-58. Kellner subsequently returned to this issue in an attempt to bolster his original conclusion; see his article, "Maimonides' True Religion-for Jews, or All Humanity," Me'orot 7 (2008) [reprinted in his Science in the Bet Midrash: Studies in Maimonides (Boston: Academic Studies Press, 2009), 291-319.

4 See Joel L. Kraemer, "Namus and Shari' in the Philosophy of Maimonides," Teudah 4 (1986): 185-202 (Heb.). See also idem, "Naturalism and Universalism in Maimonides' Political and Religious Thought," in Me'ah She 'arim: Studies in Medieval Jewish Spiritual Life in Memory of Isadore Twersky, ed. Ezra Fleischer et al. (Jerusalem: Magnes Press, 2001), 47-81. 
imperfect or incomplete one. ${ }^{5}$ This leaves open the possibility that "true religion" (dat emet) in Maimonides' depiction of the messianic future in fact refers to the Noahite laws, which will then be adopted by all gentiles. This interpretation finds further support from the use of the term "return to the true religion," more appropriately referring to the Noahite commandments, which according to rabbinic tradition were practiced by the entire world when they were first promulgated, than to Mosaic Law. ${ }^{6}$ As we shall also see, Maimonides at times uses the term "true religion" in contexts that could not possibly refer to Judaism. David Sklare has delved into the historical background of this issue in the Islamic world, dealing with Islamic and Jewish theologians who addressed the issue of whether the entire world will or should be converted to one religion. ${ }^{7}$ While many theologians were of the opinion that ideally everyone should practice the same ultimate divine religion, and some were of the opinion that this goal should be attained even by coercion, Maimonides appears to adopt a middle position on this issue. He demands of all gentiles in pre-messianic times to practice only the seven Noahite laws, and states that they should even be coerced to do so in all places where Jewish sovereignty extends. ${ }^{8}$ Moreover, they must also acknowledge the Law of Moses as the source for the obligation of observing the Noahite laws. ${ }^{9}$

In his vision of the future, it is clear that Maimonides certainly does not posit a situation of forcible conversion of the gentiles to

5 See Avraham Nuriel, Concealed and Revealed in Medieval Jewish Philosophy (Jerusalem: Magnes Press, 2000), 165-171 (Heb.).

6 This argument, however, is not decisive. "Return" in this context does not necessarily refer to a situation in which one has already been; it may refer also to a situation that one should attain. This is evident in the phrase "to return in repentance" (labzor beteshuvah), which does not connote that the individual has started out completely righteous observing all the commandments.

7 See David Sklare, "Are the Gentiles Obligated to Observe the Torah? The Discussion Concerning the Universality of the Torah in the East in the Tenth and Eleventh Centuries," in Be'erot Yitzhak: Studies in Memory of Isadore Twersky, ed. Jay Harris (Cambridge MA: Harvard University Press, 2005), 311-346.

8 See Mishneh Torah, Laws of Kings and their Wars 6.4; 8.10

9 Ibid., 8.11. 
Judaism. Just as Moses did not command the conversion of gentiles, ${ }^{10}$ so will the king-messiah refrain from such an act. If they all convert, it is because they have grasped the eternal truth and validity of Judaism. Given Maimonides' conception of the nature of Judaism and the intellectual and spiritual enlightenment characterizing all nations in the messianic age, the logic of the argument that the whole world will become Jewish in his view is compelling. Gentiles would not settle for anything less than the one true divine legislation if they have come to realize the true purpose of life and the role played by Mosaic Law in attaining that purpose, have come to recognize the lies that their forefathers have taught them in promulgating Christianity and Islam, as Maimonides points out in Laws of Kings $11.8,{ }^{11}$ and finally, have no other religious option, at least no other complete religious law that can be considered divine. Maimonides is certainly adamant on the point that there was and always will be only one complete divine lawnamely, the Law of Moses. ${ }^{12}$ Why then would I envision that Maimonides hesitates before proclaiming that the whole world will voluntarily convert to Judaism?

First, let me bring some textual support for the view that Maimonides does not think that the whole world will become Jewish. As Blidstein argues, if Maimonides felt that the whole world would in fact convert to Judaism, one would have expected a more explicit statement on the subject, some stress on this point. Moreover, Maimonides appears to see the world in the messianic times as maintaining its multi-national character. This would not be the case if everyone converted. Then everyone's nationality would be Jewish, at least according to what appears to be Maimonides' conception of nationality. ${ }^{13}$ There is then an

10 Ibid., 8.10 .

11 This passage was censored from the early printed editions of the Mishneb Torah and still does not appear in many editions. Cf. Judah Halevi, Kuzari 4.23.

12 See Guide 2.39; cf. 1.63, 3.27.

13 See Blidstein, Maimonides' Political Halakha, 247. Maimonides' position is based on the view that the proselyte becomes a full-fledged Israelite who has completely abandoned his previous identity, in accordance with the rabbinic dictum: "The proselyte is like a newborn," and hence we pay no consideration to his past. See, for example, his commentary to Mishnah Zavim 2.3. In his letter to Obadiah the 
ambiguity, if not an inconsistency, in Maimonides' view of the future. ${ }^{14}$ He must hesitate for a brief moment before unequivocally deciding the issue. I interpret him as secretly agreeing with the view that it would be sufficient for gentiles to become fellow travelers of the Jews by striving to perfect their intellects, each in accordance with one's ability, and pursuing ethical perfection, while at the same time giving his vocal assent to the view positing their formal conversion. This is intrinsically tied to his political thought.

It is well known that Maimonides in the Guide of the Perplexed makes an unusual move in proving the divinity of Judaism. Whereas in his earlier works he points to empirical proofs of its supernatural origin, namely the divine voice heard at Sinai proclaiming before all Israel the truth of Moses' prophecy, ${ }^{15}$ in the Guide he points to three different criteria as proof of its divinity: 1) the "equibalance" of its laws, particularly in its demands on limiting one's corporeal appetites $\left.(2.39) ;{ }^{16} 2\right)$

Proselyte, Maimonides reinforces the view of the complete integration of the proselyte into the Jewish people; see Isaac Shailat (ed. and Heb. trans.), Iggerot HaRambam (Jerusalem: Ma'aliyot, 1987), 233-235. In the introduction to the Mishneb Torah, he underlines the fact that two of the leading rabbinic sages, R. Akiva and R. Meir, were children of converts, in order to show that the level one achieves within the Jewish community is dependent upon one's learning and not one's origin.

14 Maimonides' view of the messianic future has been the subject of a good number of studies. For two different interpretations of his conception see in particular Amos Funkenstein, "Maimonides: Political Theory and Realistic Messianism," Miscellanea Medieavalia 9 (1977): 81-103; Aviezer Ravitzky, "To the Utmost of Human Capacity': Maimonides on the Days of the Messiah," in Perspectives on Maimonides, ed. Joel Kraemer (Oxford: Oxford University Press, 1991), 221-256 [reprinted in Ravitzky, History and Faith: Studies in Jewish Philosophy (Amsterdam: J. C. Gieben, 1996), 73-112]. An extensive bibliography dealing with this topic was compiled by Jacob Dienstag and can be found in Eschatology in Maimonidean Thought: Messianism, Resurrection, and the World to Come, ed. Jacob I. Dienstag (New York: Ktav, 1983), 242-271.

15 See, for example. Mishneb Torah, Laws of Principles of the Torah 8.1.

16 "For when a thing is as perfect as it is possible in a species, it is impossible that within that species there should be found another thing that does not fall short of that perfection, either because of excess or deficiency. Thus in comparison with a temperament whose composition is of the greatest equibalance possible in the species in question, all other temperaments are not composed in accordance with this equibalance because of either deficiency or excess. Things are similar with regard to this Law $\left(\operatorname{shari}^{-1} a\right)$, as is clear from its equibalance ... for these are manners 
the purpose of the Law, namely that it pays attention to the well-being of one's beliefs (2.40), ultimate perfection lying in one's knowledge rather than in one's deeds. ${ }^{17}$ Since legislations that imitate the divine law may also appear to share these two traits, Maimonides adds another criterion: 3) the intellectual-moral perfection of the prophet who brings the law (2.40). Only a perfect individual can receive prophecy in his view of this phenomenon. ${ }^{18}$ Maimonides is also adamant on the point that God does not miraculously bestow prophecy upon one who does not possess all the necessary natural qualifications (2.32). The Guide substitutes a rational-and, one is tempted to add, naturalistic-basis for recognizing the divinity of the divine law for the supernatural basis found in his earlier writings. There is no inherent

of which there is no burden or excess-such as monastic life and pilgrimage and similar things-nor a deficiency necessarily leading to greed and being engrossed in the indulgence of appetites, so that in consequence the perfection of man is diminished with respect to his moral habits and to his speculation-this being the case with regard to all the other nomoi of the religious communities of the past. . . . Accordingly the facility or difficulty of the Law (shari' $a$ ) should not be estimated with reference to the passions of all the wicked, vile, morally corrupt men, but should be considered with reference to the man who is perfect among the people. For it is the aim of this Law that everyone should be such a man. Only that Law is called by us divine Law ( $\operatorname{sharī'}^{-} a$ ilāhìy $\left.\bar{a}\right)$, whereas the other political regimens (al-tadbirät al-madanìät) - such as the nomoi of the Greeks and the ravings of the Sabians and of others-are due, as I have explained several times to the action of groups of rulers who were not prophets" (380-381).

17 "Accordingly if you find a Law $\left(\operatorname{shari}^{-1} a\right)$ the whole end of which and the whole purpose of the chief thereof, who determined the actions required by it, are directed exclusively toward the ordering of the city and its circumstances and the abolition in it of injustice and oppression; and if in that Law attention is not at all directed toward speculative matters . . you must know that that Law is a nomos. . . . If, on the other hand, you find a Law all of whose ordinances are due to attention being paid, as we stated before, to the soundness of the circumstances pertaining to the body and also to the soundness of belief-a Law that takes pains to inculcate correct opinions with regard to God, may He be exalted in the first place, and with regard to the angles, and that desires to make man wise, to give him understanding, and to awaken his attention, so that he should know the whole of that which exists in its true form-you must know that this guidance comes from Him, may He be exalted, and that this Law is divine (al-sharī'a ilābìyāa)" (383-384). See also Guide of the Perplexed 3.27; 3.54.

18 I analyze these chapters of the Guide in Howard Kreisel, Prophecy: The History of an Idea in Medieval Jewish Philosophy (Dordrecht: Kluwer Academic Publishers, 2001), 257-263. 
contradiction between these two approaches. Speaking philosophically, one may say that in his early writings Maimonides underlines the efficient cause of the divine law, while in his theological treatise he is more interested in stressing its final and formal causes. ${ }^{19} \mathrm{~A}$ number of interpreters, myself among them, have viewed this shift in approach not only as a tactical one, that is to say presenting the notion of divine law in a manner that will be more acceptable to rationalists, but rather as indicative of his esoteric position on the origin of divine law. The Torah does not result from God directly creating audible words to convey specific commandments to Moses' hearing, as R. Saadiah Gaon maintains, ${ }^{20}$ nor does it result from the impressing of specific laws on the mind of Moses, an internal "voice" conveying the laws. ${ }^{21}$ Rather it is the immediate product of Moses' intellectual perfection, a perfection that involves a purely intellectual and perfect understanding of the order of existence, and Moses' ability to frame a perfect Law on the basis of his theoretical understanding. ${ }^{22}$

Maimonides takes for his model Alfarabi's depiction in the Political Regime of the ideal lawgiver:

The supreme ruler without qualification is he who does not need anyone to rule him in anything whatever, but has actually acquired the sciences and every kind of knowledge, and has no need of a man to guide him in anything. He is able to comprehend well each one of the particular things that he ought to do. He is able to guide well all others to everything in which he instructs them, to employ all those who do any of the acts for which they are equipped, and to determine, define, and direct these acts toward happiness. This is found only in the one who possesses great and superior natural dispositions, when his soul is in union with the Active Intellect. . . This

19 In both his legal treatises and in the Guide he stresses unique perfection of the agent of transmission, Moses.

20 For the notion of created speech see Book of Beliefs and Opinions 2.12. For a discussion of this phenomenon see Kreisel, Prophecy: The History of an Idea, 56-68.

21 I will discuss this point in more detail below in chapter 9.

22 See Howard Kreisel, Maimonides' Political Thought (Albany: SUNY Press, 1999), 12-13, 79-81. See also Alvin Reines, "Maimonides' Concept of Mosaic Prophecy," HUCA 40 (1969): 325-362; and Kalman Bland, "Moses and the Law According to Maimonides," in Mystics, Philosophers and Politicians, ed. Jehuda Reinharz and Daniel Swetschinski (Durham: Duke University Press, 1982), 49-66. 
man is the true prince according to the ancients; he is the one of whom it ought to be said that he receives revelation (waby). ${ }^{23}$

If Maimonides finds his inspiration from Alfarabi's model, he also finds in it a challenge to the permanent validity of Judaism. Certainly the vast majority of individuals would consider such a law to be a human product. For Alfarabi, followed by Maimonides, the legislator solves this problem by creating myths indicating the Deity's personal involvement in the transmission of each of the laws. This should satisfy the masses as to the divine origin of the Law and insure their commitment. ${ }^{24}$

Yet there remains another problem that is more substantive from a philosophic perspective. Alfarabi depicts ideal legislators and polities only in theoretical terms, without dealing explicitly with Islam. His theoretical model enables him to posit successive ideal legislations stemming from more than a single ideal lawgiver. Each lawgiver frames a legislation fitting to one's own time and place. In the periods between the emerging of ideal lawgivers, subordinate lawgivers assume the task of adapting the existing legislation to changing circumstances..$^{25}$ There is nothing in the model itself that suggests that one lawgiver will be the

23 The passage was translated by F. M. Najjar and appears in Medieval Political Philosophy, ed. Ralph Lerner and Muhsin Mahdi (Ithaca: Cornell University Press, 1972), 36. It should be noted that Alfarabi in his various writings does not use the term "divine religion" but "virtuous (fadila) religion." See in particular his Book of Religion, in Alfarabi: The Political Writings, trans. Charles E. Butterworth (Ithaca: Cornell University Press, 2001), 93-98.

24 For a study of Alfarabi's political thought, see Miriam Galston, Politics and Excellence: The Political Philosophy of Alfarabi (Princeton: Princeton University Press, 1990). The importance of the prophet teaching by means of images of the truth and laying down activities that are designed to preserve the people's commitment to the law is elaborated by Avicenna; see the selection from Al-Shifā: Al-Ilāhiyyāt translated by Michael Marmura that appears in Medieval Political Philosophy, 100-101. Maimonides' indebtedness to Alfarabi's political philosophy has been much discussed in scholarly literature, following the classic studies of Leo Strauss on this issue, such as his "Farabi's Plato," in Louis Ginzberg Jubilee Volume, ed. Alexander Marx et al. (New York: American Academy of Jewish Research, 1945), 357-393. See, for example, Lawrence Berman, "Maimonides, the Disciple of Alfarabi," Israel Oriental Studies 4 (1974): 154-178.

25 See Political Regime, 37. 
seal of all prophets and lawgivers, as Moslems regard Mohammed. Quite the contrary, the model suggests that as long as there are historical changes there is room for new divine legislations. Maimonides leaves little doubt that he sees some of the laws outmoded, namely those involving sacrifices that are laid down in accordance with the "second intention" of the law as he terms it—that is, they do not lead to perfection directly but are promulgated as a compromise measure out of consideration to historical circumstances. ${ }^{26} \mathrm{He}$ nevertheless is adamant on the issue that there never was or will be another divine legislation. ${ }^{27}$ Given the historical context in which all laws are framed, it will do little good to argue that theoretically speaking, even if any prophet attained Moses' perfection he would not lay down a new law, insofar as the law, like nature, is completely perfect, and any change, either addition or deletion, would detract from its perfection. ${ }^{28}$ This argument ignores the fact recognized by Alfarabi that changes in historical circumstances would call for framing a different divine law. Once Sabian practices are largely obliterated, it appears to be pointless to continue to uphold a divine law that is devoted in such large measure to countering them. New threats to ethical monotheism should be given more consideration. Maimonides himself appears to recognize that a superior divine law is possible. While explaining why God commanded sacrifices despite the fact that they do not belong to the primary intention of the law-that is, they do not contribute to perfection in a direct manner-he states:

His wisdom, may He be exalted, and His gracious ruse, which is manifest in regard to all His creatures, did not require that $\mathrm{He}$ give us a Law prescribing the rejection, abandonment, and abolition of all these kinds of worship. For one could not then conceive the acceptance of [such a Law], considering the nature of man, which always likes that to which it is accustomed. At that time this would have

26 Guide 3.32 .

27 Ibid. 2.39; 3.27. See also the ninth principle of Judaism that Maimonides presents at the end of his introduction to Pereq Heleq in his Commentary on the Mishnah; and Mishneb Torah, Laws of Principles of the Torah 9.1.

28 See above, note 16. Maimonides makes a similar point when discussing miracles and permanent changes in nature in Guide 2.28. 
been similar to the appearance of a prophet in these times who, calling upon the people to worship God, would say: "God has given you a Law forbidding you to pray to Him, to fast, to call upon Him for help in misfortune. Your worship should consist solely in meditation without any works at all." (Guide 3.32: 526)

How then are we to understand the paradox that Maimonides, one of the more historically inclined thinkers regarding the reason for many of the commandments of Mosaic Law, adopts what appears to be a completely ahistorical position when it comes to its eternal validity?

The answer lies in Maimonides' commitment to Judaism. Maimonides never looks at Judaism as an outsider. The way he approaches this issue is how can one best understand, defend, and promote the Torah as a divine legislation in his own period in a manner that at the same time conforms to his understanding of the nature of divine activity. While Maimonides may actually have thought that he could dismiss the divine character of Christianity and Islam on philosophical grounds by pointing to the defects in the content of the religions and in those who were responsible for laying them down, ${ }^{29}$ he certainly had no strong rational argument to eliminate the possibility that there will emerge a prophet equaling Moses' perfection, who would lay down a new divine law. Such argument can only be based on traditional grounds or political ones. It certainly is not a demonstrative claim from a philosophic perspective. There are traditional statements that Maimonides employs in support of this position, ${ }^{30}$ but I regard the political considerations as

29 Maimonides devotes much of his Epistle to the Jews of Yemen to this objective. He also hints to Mohammed's unfitness as a prophet in Guide 2.40. As for Christianity, belief in the Trinity and of God assuming a human form made it an easy target for the polemics of Moslems and Jews alike who accepted the philosophic doctrine of a single incorporeal deity. For a study of anti-Christian philosophical polemics, see Daniel J. Lasker, Jewish Philosophical Polemics against Christianity in the Middle Ages (New York: Ktav, 1977).

30 In addition to attempting to prove this point on the basis of biblical verses, Maimonides also cites rabbinic statements-for example, prophets are not allowed to introduce any innovation in the Law after its reception; see BT Shabbat 104a. Prior to Maimonides, R. Saadiah Gaon already argued at length against the abrogation of the Torah, employing both rational considerations and biblical textual ones; see Book of Beliefs and Opinions 3.7-10. 
more important. He is writing in a period during which three revelatory religions are vying for supremacy (leaving aside Eastern religions), and from a historical perspective Judaism is in last place. ${ }^{31}$ To concede even the possibility of changes in Judaism in the future is to weaken one's defense against the view that these changes have already occurred in the past, namely by the founders of the other religions. This would make it easier to undermine the commitment of Jews in the present to their ancestral religion. ${ }^{32}$

Maimonides at times was faced with the necessity of addressing the contemporary situation directly in an effort to prevent Jews from converting. The arguments he makes in the Guide for identifying the characteristics of the divine religion previously appeared in his Epistle to the Jews of Yemen, in which he deals with Christianity and Islam explicitly. Taking a page from Halevi, Maimonides views these religions as poor, lifeless imitations of the "divine religion" (din ällāh) and

31 This problem is the starting point for Halevi's Kuzari. If might does not make right, it at least is reflective of right, or of God's favor, in the minds of the populace.

32 Maimonides writes in Guide 3.34: 534-535: "In view of this consideration, it also will not be possible that the laws be dependent on changes in the circumstances of the individuals and of the times, as is the case with regard to medical treatment, which is particularized for every individual in conformity with his present temperament. On the contrary, governance of the Law ought to be absolute and universal, including everyone, even if it is suitable only for certain individuals and not suitable for others; for if it were made to fit individuals, the whole would be corrupted." While the problem of abrogation is not discussed in this passage, Maimonides' view suggests that allowing for even the slightest change in the Torah would lead to undermining the entire legislation. He is adamant in his insistence that one should view the Law of Moses as an immutable whole, a point that is underscored by his codification of all the Mosaic commandments in his Mishneb Torah, including those concerning the service of the Temple that were not relevant to his own period. This point is also reflected in the extreme stance he adopts in distancing prophecy from any legislative/judicial role. I discuss this issue in greater detail in "Maimonides' Political Philosophy," in Cambridge Companion to Moses Maimonides, ed. Kenneth Seeskin (Cambridge: Cambridge University Press, 2005), 204-206. See also Kreisel, Prophecy: The History of an Idea, 159-167, 198-200; Kreisel, Maimonides' Political Thought, 23-29; Gerald Blidstein, "On the Institutionalization of Prophecy in Maimonidean Halakha," Daat 43 (1999): 25-42 (Heb.). 
the "true religion" (al-din al-baqiq $\overrightarrow{\text { ) }} .^{33}$ The constant repetition of these terms in this context serves to counter the claims of the competing religions and stress Judaism's exclusivity.

If Maimonides posits Mosaic Law as the one eternal divine religion, he is not being insensitive to the relation between divine law and historical realities, but he is rather being very sensitive to his current reality that requires a vigorous defense of Judaism. On a practical level, changes in historical realities are to be met by the various powers bestowed by Mosaic Law upon the rabbinic authorities in every generation, who assume the task Alfarabi ascribes to the subordinate lawgivers who adapt the divine Law to their own period. For Maimonides, the only way to preserve the whole is to deny any formal change in any of its parts. Mosaic Law in fact continuously evolves due to the activity of the legal institutions responsible for its interpretation and the various powers accorded them, while no commandment is ever formally abrogated. Maimonides essentially adopts the model of the virtuous religion that he found in the writings of Alfarabi in order to understand, defend, and adapt Jewish law to his own time in accordance with his view of the factors that make a law divine-namely, its purpose and the way it goes about attaining it. ${ }^{34}$ In an exceptionally innovative and highly significant move, Maimonides opens his great legal code, Mishneh Torah, with two sections that are devoted to bringing about the "welfare of the soul," that is, correct opinions concerning God and the world, and the "welfare of the body," that is, ethical traits. These are the two purposes of the divine law presented by Maimonides in Guide 3.27.

Maimonides' response to historical circumstances finds expression in yet another interesting way in a context in which he deals with the divine law. In the "Laws of Kings," Maimonides essentially transforms

33 See Shailat, Iggerot HaRambam, 86-87 (Heb., 121-123). Maimonides also employs there (87) the term "the true divine religion" (al-sharica al-ilābìyā al-ḅaqìqù). See Halevi, Kuzari 3.9; see also Daniel J. Lasker, "Proselyte Judaism, Christianity, and Islam in the Thought of Judah Halevi," JQR 81 (1990): 75-91.

34 See Warren Z. Harvey, "Political Philosophy and Halakhah in Maimonides," Iyyun 29 (1980): 198-212 (Heb.); see also Kreisel, Maimonides' Political Thought, $21 \mathrm{ff}$. 
optional wars waged by a Jewish sovereign into holy wars by making it the duty of the sovereign to insure that all the vanquished adopt the seven Noahite laws. ${ }^{35}$ This transformation can be seen also in the terminology he employs in "Laws of Kings" 7.15 when dealing with the desired mindset of the soldiers marching off to an optional war: "He should know that he is waging war in order to unify God." As early as the Book of Commandments (positive commandment no. 191), where Maimonides deals with the anointed priest who addresses the troops before marching off to battle, this point clearly emerges: "He should add to this words that stir up the nation for war and bring them to sacrifice their lives for the victory of the divine religion (din älläh) and revenge upon those ignorant of it who corrupt the order of society." "Divine religion" in this context does not appear to refer to the Noahite laws but to the Mosaic Law that commands their enforcement. This also is the purport of his statement in "Laws of Kings" 4.10: "In every matter, his [the king's] acts should be for the sake of heaven, and his thought and intention to elevate the true religion (dat ba-emet) and to fill the world with justice." One need not go far to find the primary sources for Maimonides' position and terminology when dealing with war-namely, the same Islam against which Maimonides polemicizes. ${ }^{36}$ While Judaism may be powerless at the current stage of history to engage in jibād or Crusades, Maimonides develops a model based on traditional sources that is designed to address the aspirations of his coreligionists at the same time that he attempts to mold their aspirations (and their historical memory) in response to the views and practices of the other religions.

35 See Ralph Lerner, "Moses Maimonides," in History of Political Philosophy, ed. Leo Strauss and Joseph Cropsey (Chicago: Chicago University Press, 1963), 181-200; Blidstein, Political Concepts in Maimonidean Halakha, 230-245.

36 This point is also true of Maimonides' decision to formulate principles of faith, his role model being the fanatical Almohades, who were the cause of so much suffering experienced by Andalusian Jewry including Maimonides and his family. See Shlomo Pines, "Lecture on Maimonides' Guide of the Perplexed," Iyyun 47 (1998): 115-128 (Heb.). The article was prepared from Pines's manuscript by Sarah Stroumsa and Warren Z. Harvey. 
In his treatment of the Noahite laws in Mishneb Torah, Laws of Kings 8.11, Maimonides introduces a very controversial point that has important bearing on our topic as well as on his philosophy in general. He insists that gentiles observe these laws based on an acceptance of the revelation of the Torah and not because of an "inclination of the intellect" (hekbre'a ha-da'at). Without this acceptance, one is not considered to be a righteous gentile (who merits a portion in the World to Come) and one who wishes to live in Israel would be denied the status of a resident alien. One who observes these laws due to an inclination of the intellect is labeled by Maimonides a sage, at least in accordance with the preferred reading (from a textual and philosophic standpoint) of the passage in question. ${ }^{37}$ Maimonides deliberately leaves ambiguous the status of this individual and whether he attains a share in the World to Come. ${ }^{38}$ By adding the clause that Noahites must follow the laws based on an acceptance of the revelation to Moses, Maimonides achieves two objectives: 1) belief in one God, who is a God of revelation (note that without this clause an atheist might have no problem in fulfilling the demands of the Noahite laws); 2) a more solid foundation for morality than the popular conceptions of the masses and perhaps even the conceptions of the philosophers-a point on which Leo Strauss devoted so much of his thought. ${ }^{39}$

37 Instead of reading "is not a resident alien and not a philosopher," one should read ". . . but a philosopher," substituting the letter aleph for the letter vav, followed by the letters lamed aleph (ela instead of ve-lo). While the older standard printed editions read the word with vav, the better manuscripts and most of the newer editions read it with aleph. The subsequent furor this position stirred up, particularly after Spinoza's famous critique of Maimonides at the end of the fifth chapter of his Tractatus Theologico-Politicus, is well known. Scholars continue to argue the basis for Maimonides' ruling and even its very meaning, particularly given the controversy over the correct textual reading. For a study of this issue see Steven S. Schwarzschild, "Do Noachites Have to Believe in Revelation?" JQR 52 (1962): 297-365 [reprinted in Schwarzschild, The Pursuit of the Ideal, ed. M. Kellner (Albany: SUNY Press, 1990), 29-60].

38 See Michael Nehorai, "How a Righteous Gentile can Merit the World to Come," Tarbiz 61 (1992): 31-82 (Heb.); Hannah Kasher, "The Torah as a Means of Achieving the World to Come," Tarbiz 64 (1995): $301-306$ (Heb.). See also Kreisel, Maimonides' Political Thought, 65-71. For a possible reason for this ambiguity, see below.

39 See in particular Leo Strauss, "The Law of Reason in the Kuzari," PAAJR 13 (1943): 47-96 [reprinted in his Persecution and the Art of Writing (Chicago: Chicago University Press, 1988): 95-141]. 
Presumably, in messianic times the gentiles, having already becoming righteous because of their acceptance of the belief in the revelation to Moses, and not solely because of their understanding of the wisdom of the Noahite laws, will take the final step and become full converts.

Yet my interpretation of Maimonides' view of messianic times is not without its problems when considered in light of other statements of his on the subject. Maimonides' depiction of the ideal future in Guide 3.11 appears to suggest a different conclusion:

These great evils that come about between the human individuals who inflict them upon one another because of purposes, desires, opinion, and beliefs, are all of them likewise consequent upon privation. For all of them derive from ignorance, I mean from a privation of knowledge. ... If there were knowledge, whose relation to the human form is like that of the faculty of sight to the eye, they would refrain from doing any harm to themselves and to others. For through the cognizance of the truth, enmity and hatred are removed and the inflicting of harm by people on one another is abolished. ... Then it gives the reason for this, saying that the cause of the abolition of these enmities, these discords, and these tyrannies, will be the knowledge that men will then have concerning the true reality of the deity, for it says: They shall not burt nor destroy in all My boly mountain; for the earth shall be full of the knowledge of the Lord as the waters cover the sea [Isaiah 11:9]. Know this. (440-441)

The knowledge to which Maimonides refers is not necessarily attained only by way of the divine Law. There is nothing in the context of the discussion to suggest this conclusion. The reference here is to the knowledge of God, of the purpose of human existence and of morality that is possessed also by the philosophers. The Law is not an end in itself but ultimately serves as a means to the end of true knowledge-a point that Maimonides makes explicit in Guide 3.27. The role Maimonides ascribes to the true religion in promoting true knowledge explains some of his more radical moves as a legal authority, particularly in dogmatizing belief in an incorporeal deity. He repeatedly alludes to the view that intellectual perfection, and not Jewish 
observance per se, is the basis for attaining immortality. ${ }^{40}$ Because of the connection between religion and knowledge, While Maimonides normally uses "true religion" to designate Mosaic Law, in his response to Obadiah the Proselyte the term is used to indicate true beliefs: "Abraham our father taught all the people, educated them, and informed them the true religion (dat ba-emet) and the unity of God." 41 For this reason too, the most important distinguishing feature of Maimonides' messianic future is the pursuit of knowledge of God, with all other features serving as a means to this activity. In short, the ideal social and material conditions in messianic times will enable one to engage more fully in the fulfillment of the Torah, which in turn leads to striving to attain knowledge of God to the utmost of one's capacity. ${ }^{42}$ Yet given the superiority of knowledge over deed, the role of Mosaic Law in attaining perfection is at the same time an ambiguous one. It is concerned primarily with deeds on one hand, and it provides little of the philosophic-scientific knowledge, at least in an explicit manner, that constitutes intellectual perfection, on the other. ${ }^{43}$ For this reason there is a significant gap between divine law and ultimate knowledge, which Maimonides' depiction of the messianic future in the "Laws of Kings" does not entirely bridge.

In the final analysis, Maimonides' stress on belief in the revelation to Moses in "Laws of Kings" is due to the consideration that this belief is necessary for all of the world's masses, for they, due to their limited

40 See, for example, Mishneh Torah, Laws of Principles of the Torah 4.9; Guide 3.8; 3.51. For a study of this issue see Alexander Altmann, "Maimonides on the Intellect and the Scope of Metaphysics," in Von der Mittelalterlichen zur modernen Aufklaerung (Tubingen: J.C.B. Mohr, 1987), 85-91. See also Kreisel, Maimonides' Political Thought, 141-149.

41 Yehoshua Blau (ed. and Heb. trans.), R. Moses b. Maimon: Responsa (Jerusalem: Mekize Nirdamim, 1960), 549. Cf. Shailat, Iggerot HaRambam, 233, where the alternate reading "way of truth (derekb ha-emet)" is brought. Derekb ha-emet occurs in other passages in Maimonides' writings to indicate the holding of true beliefs. See, for example, Mishneh Torah, Laws of Idolatry 1.3. Maimonides' usage of dat ha-emet in Mishneh Torah, Laws of Leavened and Unleavened Bread 7.4, is ambiguous; while it may refer to Mosaic Law it may also refer to the attainment of true beliefs.

42 See Introduction to Pereq Heleq; Mishneb Torah, Laws of Repentance 9.1-2.

43 I deal with this issue in more detail in Maimonides' Political Thought, 189-223. 
intellect, will always require belief in the divine Law to insure their acceptance of the monotheistic idea and the practice of morality, even in messianic times. Maimonides is not so utopian as to believe that everyone will become philosophers. Thus in messianic times there will be no more crime, because everyone will possess the knowledge necessary for its prevention by one means or another-the masses by way of belief in revelation and the philosophers by way of intellectual understanding. At the same time, the philosophers will realize that the divine Law presents these same truths in a manner appropriate to the masses. Those who achieve true knowledge of philosophy understand God and strive for human perfection independent of the mandates of the Law. In their case, the belief in the revelation of the Law or even a formal conversion to Judaism would not appear to add to their perfection. However, they will always remain few, even in messianic times, and the Law is aimed at the majority. ${ }^{44}$

This brings us to the problem of where the gentile sage stands in relation to perfection in comparison to an observant Jew in Maimonides' thought. We have seen above that Maimonides is ambiguous in his definition of the status of this individual. There is little doubt that Maimonides as a philosopher must answer that such an individual stands on a much higher plane than the observant Jew who is ignorant of all philosophy and science. Moreover, if immortality of the intellect, which is how Maimonides defines the World to Come, is consequent on intellectual perfection, it is the philosophical elite, irrespective of their religion, who attain this state, and not the masses of Jews. Yet Maimonides as a rabbinic scholar cannot indicate the superiority of the former, at least not explicitly, for to do so would undermine much of his activity in bolstering the edifice of Jewish law.

44 Guide 3.34. It may further be argued that even if Maimonides accepted the theoretical possibility of framing a better divine Law in the future, there will be no real need to do so, just as there is no need in Maimonides' own time. The need then as now is to interpret Mosaic Law in a manner that is most conducive to the pursuit of true knowledge of God and best insures social morality, including the curbing of one's physical passions. 
The superiority of knowledge over deed in Maimonides' thought, and the deliberate ambiguity in his approach to the gentile philosopher, finds expression also in the most famous parable in Guide 3.51-that of the king in his palace. ${ }^{45}$ The reader is struck by how far the observant masses are from reaching the king in Maimonides' view; they do not even see the walls of the palace. Even more striking is the fact that he depicts the great Torah scholars who lack philosophic knowledge as still looking for the entrance to the palace. The importance of philosophicscientific knowledge in attaining perfection receives a vivid expression in Maimonides' explanation of the parable. This is particularly true in the second explanation Maimonides provides for the parable, in which proximity to the king is depicted in terms of mastering the various sciences in their proper order. ${ }^{46}$ A closer examination of Maimonides' explanation of the parable reveals that his omission is no less striking. For all of his stress on philosophic knowledge in his explanation of how to reach the king, and the not so subtle downplaying of the role of all the commandments in this matter, at least those involving physical actions, one person or group is conspicuous by their absence-namely, Aristotle and his followers. Where does the "head of the philosophers," as Maimonides calls Aristotle, ${ }^{47}$ stand in relation to the king?

45 For a detailed study of this parable, see Menachem Kellner, Maimonides on Human Perfection (Atlanta: Scholars Press, 1990); and Hannah Kasher, "The Parable of the King's Palace in The Guide of the Perplexed as a Directive to the Student," AJS Review 14 (1989): 1-19 [Hebrew Section]. I discuss this parable also below in the introduction to chapter 4, 73-77.

46 In the first explanation of the parable, the ones who are near the walls of the palace but are looking for the gate are "the jurists who believe true opinions on the basis of traditional authority and study the law concerning the practices of divine service, but do not engage in speculation concerning the fundamental principles of religion and make no inquiry whatever regarding the rectification of belief" (619). Those who have plunged into speculation have entered the antechambers. In the second explanation of the parable, Maimonides indicates that those who have not progressed beyond the study of logic and the mathematical sciences are still searching for the gate, while those who understand the natural sciences have entered the antechambers. Maimonides suggests that the second explanation complements the first. The question arises whether he sees it as an alternative to the first.

47 Guide $1.5 ; 2.23$. 
It is an untenable interpretation, in my view, to hold that Maimonides sees Aristotle as belonging to the group that "have turned their backs upon the ruler's habitation," whom he defines as "people who have opinions and engaged in speculation, but who have adopted incorrect opinions either because of some great error that befell them in the course of their speculation. . . Accordingly, because of this opinion, the more these people walk, the greater is their distance from the ruler's habitation. And they are far worse than the first. They are those concerning whom necessity at certain times impels killing them and blotting out the traces of their opinions lest they should lead astray the ways of others" (619). Maimonides is referring to polytheists and atheists in his description of this group, for they have committed the greatest error of all in the opinions they hold. ${ }^{48}$ For Maimonides, Aristotle is the great monotheistic philosopher, the one who provides philosophical proofs against Epicurus and shows the general providence God exercises toward the world. ${ }^{49} \mathrm{He}$ certainly should not be classed together with that ignoble philosopher. Nowhere does Maimonides speak of Aristotle with less than complete respect, even in those places where he apparently disagrees with him. It is Aristotle's writings, together with those of his most important commentators, that Maimonides indicates to the translator of the Guide, R. Samuel Ibn Tibbon, that he must read in order to understand the treatise. ${ }^{50}$ Aristotle, whose work on metaphysics, let alone other sciences, remained for Maimonides the most important treatise ever written on the subject and indispensable to the pursuit of intellectual perfection, clearly deserves a place close to the prophets in his thought, and hardly should be seen as belonging to the group that he condemns more than all others. The reason for Maimonides' striking omission is clear. To indicate explicitly how close Aristotle stands in relation to the king would undermine

48 See Mishneb Torah, Laws of Kings and Wars 6.4, in which Maimonides rules that the Canaanites and Amaleqites are killed only if they do not accept the Noahite laws. For Maimonides, it is people's beliefs that are the most important consideration in determining their status.

49 Guide 3.17.

50 Shailat, Letters and Essays of Moses Maimonides, 552. 
Judaism, for it would lead many to conclude that Judaism is not indispensable, and perhaps not even the superior path to perfection. Silence in this case is the better part of valor. Here, as in the case of his depiction of the messianic future, Maimonides walks a thin line between teaching the central role of philosophic knowledge in Judaism while trying to keep his readers from concluding that Judaism is not necessary for reaching ultimate perfection. Maimonides, like nature and the Law, cannot pay attention to the isolated in addressing his coreligionists. He is not writing for the exceptional philosopher who has attained perfection, but for the masses of Jews and the few potentially perfect, and he is interested in guiding them to perfection by way of Judaism.

One's vision of the future, just as one's reconstruction of the past, at least when you are talking about leaders and public educators, is always about the present. It is about how one sees the current situation and to what destination one seeks to guide the audience in their present circumstances. Maimonides' depiction of messianic times is not an exercise in divination, is not based on what he sees as an inevitable natural process operating in history, ${ }^{51}$ nor on a simple reconstruction of traditional statements on the subject. One may even question to what extent he is concerned with what will actually happen sometime in the indefinite future. His code of Jewish law is for his time and not necessarily for all time. ${ }^{52} \mathrm{He}$ is concerned with what is happening to the Jewish people in the present, and how the situation is to be improved: how Jews in their current circumstances can best be guided to realize the true goal in life as human beings, how Jewish law can best be interpreted and implemented to achieve this goal, and how the past and the

51 Interestingly, R. Nissim of Marseille, in his discussion of Maimonides' principles, does view the coming of the messiah as an inevitable event from a philosophic standpoint. He bases this position on the Aristotelian principle that what in possible must inevitably occur in the course of eternity. See Ma'aseb Nissim, 156.

52 That is to say, according to my view of Maimonides' historical consciousness and his playing the role that Alfarabi ascribes to subordinate lawgivers, he accepts the fact that others like him will arise in the future who will play a similar role and write codes based on their interpretations and in accordance with the circumstances of their period, while maintaining the inviolability of the Mosaic commandments. 
future can be reconstructed to best teach this goal. He includes all the commandments in his code, and not only those practiced in his period, not because he sees his code as the one that will govern the future Sanhedrin, but because it is crucial that Jews in his own time view the Torah as a complete and single body of law that is inviolate, in order to meet the contemporary challenges.

Therefore, I think Maimonides would hesitate for a brief moment while considering all these points before answering what he must answer when confronted with the issue of whether all gentiles would become Jews in the messianic future. His uppermost consideration would be a political-pedagogical one: what will be the repercussions of his answer for Jews in his own time? What conclusions will they draw if he paints a picture of an ideal future in which all pursue the same goal but in different ways, not bound by uniform obligations? While the distinction between Jews and other nations in the messianic future may be important for reinforcing a sense of Jewish peoplehood, does it add to an appreciation of the role of Mosaic Law in attaining perfection or detract from it? In the final analysis, all answers about the future must serve to bolster the commitment of the Jewish people to Judaism in the present, at the same time that they contribute to appreciating the true nature of Judaism as a divine religion. 